\title{
roous 11
}

Faculty and Student Work

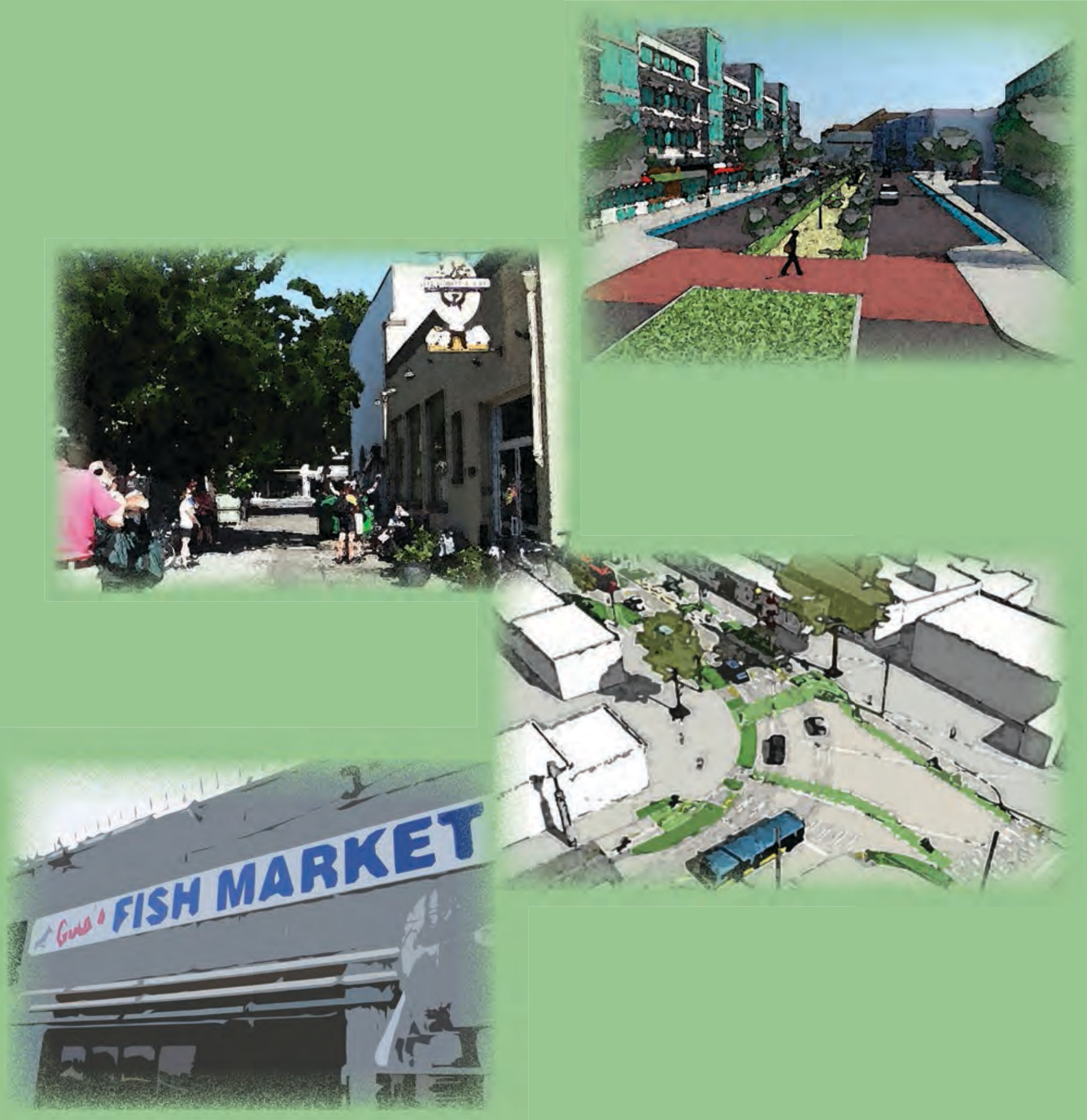

